\title{
Effect of Material Used in Concrete Mixture on the Foundation Stresses on Soil
}

\author{
Entidhar Al-Taie, Nadhir Al-Ansari, Sven Knutsson \\ Department of Civil, Environment and Natural Resources Engineering, Lulea University of Technology, Lulea, \\ Sweden \\ Email: Entidhar.altaie@ltu.se, Nadhir.alansari@ltu.se, Sven.Knutsson@ltu.se
}

Received 23 September 2015; accepted 27 October 2015; published 30 October 2015

Copyright (C) 2015 by authors and Scientific Research Publishing Inc.

This work is licensed under the Creative Commons Attribution International License (CC BY).

http://creativecommons.org/licenses/by/4.0/

(c) (i) Open Access

\begin{abstract}
Sustainable design, green architecture and sustainable construction are new methods for design and construction that are employed for environmental and economic challenges. Clay and bricks proved as sustainable building materials. In this paper, crush brick in the concrete mixture instead of normal coarse aggregate will be used. STAAD Prov8i software was applied for the designed of a hypothetical building in different sites of the three locations in Iraq (Mosul at the north, Baghdad at the center and Basrah at the south). The input model data used in the software were depending on the field and laboratory tests done for twenty three sites in the three locations of Iraq. Concrete properties values were used in the software for concrete mixture with crushed bricks. The results values of base pressure obtained from the software were low for the three locations. The maximum values of base pressure under the foundation for both the average and the minimum bearing capacity values for Mosul region for the normal strength concrete and air-entrained were $(94,84) \mathrm{kPa}$ and $(91,82) \mathrm{kPa}$ respectively, for Baghdad region were $(89,82) \mathrm{kPa}$ and $(86,81) \mathrm{kPa}$ respectively. Finally, for Basrah, the results for the base pressure were $(84,77) \mathrm{kPa}$ and $(82,76) \mathrm{kPa}$, respectively. The results values of the base pressure were less for all locations compared with the base pressure values obtained from a previous work for the same locations. The use of crushed brick as aggregate in the concrete mixture is economical due to its availability as local material and it is durable materials with low weight.
\end{abstract}

\section{Keywords}

Crush Brick, Sustainable Material, Base Pressure, STAAD Prov8i Software, Mud

\section{Introduction}

Sustainable design, green architecture and sustainable construction are new methods for design and construction 
used for environmental and economic challenges (Figure 1). The new buildings are designed and implemented using methods and techniques that contribute to reduction of the impact on the environment and at the same time lead to lower costs and, in particular, cost of operation and maintenance. In the twentieth century, Iraqi constructions started to be influenced by modern trends in planning and architecture. They formed the modern environment but are not characterized by sustainability, due to the mismatch between the goals of urban and the natural reality. Urban growths ignored the various environmental and humanitarian factors when planning new buildings. One of the most sustainable city planning standards must be environmental compatibility and taking into account the technology and renewable energy resources. This has to be the goal in the new urban communities in Arab cities, especially in the desert areas [1]. Many sustainable materials can be used in new cities such as brick, recycling of waste materials, steel structural framing, glass and cladding, etc.

Iraqis from ancient eras used mud in their building and architecture because Mesopotamian soil is muddy and fertile. They used it in different methodologies according to the natureand the function of the building. They used it either in its pure form or by mixing it with other materials such as straw. Also they used it as raw bricks in different ways either for the whole building or parts of it and for the finishing parts such as roofing for instancebable [2].

Now a day, concrete becomes the most widely used construction material. Concrete is a mixture of cement, aggregates (coarse such as stone and fine such as sand) and water. Many researchers studied the effect of replacing natural coarse aggregate by crushed clay bricks on the properties of concrete. Abib, et al. [3] has worked on replacing a portion of cement in concrete by clay fired at a temperature of $800^{\circ} \mathrm{C}$ to $900^{\circ} \mathrm{C}$. A waste of crushed bricks of $5 \%$ has been added to help not only to improve the tensile and the compression, but also to support a better rheological behavior in terms of fluidity and stability, with a low heat of hydration.

Dey, et al. [4] worked was due to the leakage in coarse aggregates in some parts of India for which only stone aggregate were used, as a result, the cost of construction raised up. Researchers worked to check the feasibility of using brick aggregates made from locally material mixed with standard concrete (M25 to M55). The major problem faced the researcher was the high water absorption (12\% to $20 \%$ by mass) of brick aggregates. An experimental work had been made to suggest a realistic solution. Various strength parameters, fire resistance and workability of brick aggregates concrete were checked. The results showed that concrete could be mixed with crushed brick aggregates. The concrete have heat resistance up to $6000^{\circ} \mathrm{C}$.

Bhanbhro, et al. [5] studied and evaluated the basic properties of concrete derived from local recycled bricks from Nawabshah city, Pakistan. The results obtained reduced the density up to $16 \%$ as compared to regular concrete. Concrete compressive strength obtained using recycled aggregates was $23.2 \%$, $34 \%$ and $37 \%$ less compared with concrete using regular aggregates for 7, 14 and 28 days of curing period respectively.

Kallak [6] studied the feasibility of used crushed bricks instead of the coarse aggregate (gravel) in concrete. The results obtained from the use of the crushed bricks reduced the strength of concrete. Moreover, the percentage of water to cement ratio increased as well.

Rekha [7] checked the suitability of using low grade recycled aggregates for concrete production. The experiments were performed to find out the effects of high temperatures on the properties of a standard recycled brick aggregates (concrete mix with $25 \%$ of crushed clay bricks as a coarse aggregate) and granite aggregate. The two type of aggregates used in the concrete mixture were subjected to temperatures ranging from $100^{\circ} \mathrm{C}$ to at an interval of $1000^{\circ} \mathrm{C}$ for three hours. The results gave that the concrete mixed with crushed clay bricks performed better than concrete mixed with granite aggregate.

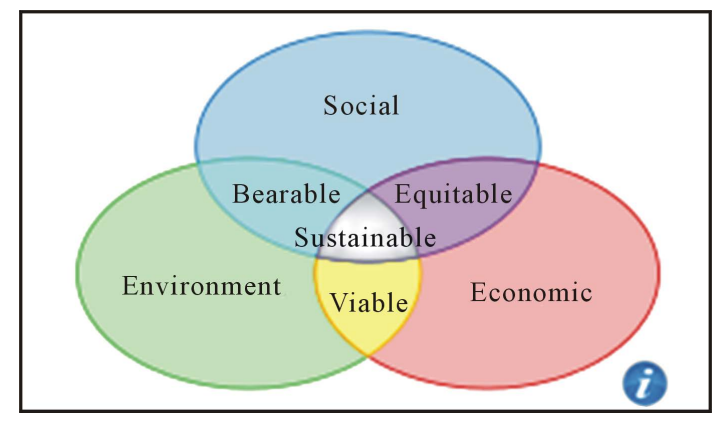

Figure 1. Sustainability plan. 
This paper will presented the effect of using crush brick in the concrete mixture as coarse aggregate on the stresses of the foundation on the soil. Design and analysis for a hypothetical building of two stories built using concrete mixed with crush brick was used and analyzed using STAAD Prov8i software. The design and the analysis of the building obtained for three locations at Mosul, Baghdad and Basrah at the northern, centeral and southern parts of Iraq. Compressive strength and density of concrete used in the software depending on the results obtained by [8].

\section{Methodology}

\subsection{STAAD Prov8i Modelling}

STAAD. Prov8i is integrated and comprehensive finite element analysis and design software. It is used as a tool for achieving the analysis and design of wide variety types of structures. Three basic activities are to be carried out to achieve the goal. These are: model generation; the calculations to obtain the analytical results and finally, result inquest is to be all facilitated by tools contained in the graphical environment of the software [9]. It is originally developed in Yorba Linda, CA by research engineers international. The software supports several steel, concrete and timber design codes. It can make use of various forms of analysis and use also various forms of dynamic analysis [10]. Moreover, the software is supporting standards of several countries. The procedure of using the software includes modeling the structure, applying properties, specifications, loads and load combinations. Also, it is an effective tool for the three dimensional model analysis and multi-material designs [11]. STAAD. Pro features are a powerful analysis and design engines, visualization tools, user friendly interface, provides an efficient, fast, easy to use and accurate platform for analyzing and designing structures. Various Loads can be used in the software such as Dead load, Live load, Earthquake loads and their suitable combinations [12]. In this work, a hypothetical building of two stories with raft foundation of $25 \times 60 \mathrm{~m}$ dimensions was designed and analyzed. The dead and live loads used were $53.5 \mathrm{KN} / \mathrm{m}^{2}$ and $8 \mathrm{KN} / \mathrm{m}^{2}$ respectively for the three locations (Mosul, Baghdad and Basrah). The design was according to ACI code [13].

Material properties used in the software depended on the tests conducted for concrete mixture using crushed new clay brick as coarse aggregate [8]. Materials used were: ordinary Portland cement (BSI2000a, b; ASTM 1994), fine aggregate, four types of clay bricks and granite. The experimental procedure was designed for concrete mixtures for each of the four new brick aggregates and the granite aggregate. The crushed bricks had been submerged in a bucket of water for a period of $30 \mathrm{~min}$. The aggregate was towelled dried to remove any excess water on the surface of the crush brick [8]. The crushed new brick absorption had values between $6.2 \%$ and $12.4 \%$ by weight in relation to the material in its dry state. The experiments were performed for five phases to study if the new crushed brick aggregate could be used as a coarse aggregate to produce concrete of a higher strength, normal strength, air-entrained, with varying water/cement ratios, increased workability, concrete without prewetting aggregate, and admixtures [8]. The results obtained from all the mixtures phases were for the concrete density of 28 days. Also, Concrete compressive strength obtained for 7, 14, 28 days for all phases. Moreover, the results were obtained for concretes produced with granite as a coarse aggregate. The compressive strength of the new bricks before crushed down into a coarse aggregate, were measured for comparison with the compressive strength of the concrete made with such bricks as aggregates [8]. In this paper the magnitudes of compressive strength and density of concrete for 28 days were used in the software.

\subsection{Study Area}

Three locations were chosen for the work: Mosul, Baghdad and Basrah (Figure 2). These locations have different geological nature.

\subsubsection{Mosul Region}

This region cover part of the foothill zone and the north part of Al-Jezira desert (Figure 2). The region is characterized by its anticlines. Clay soil is covering most of Mosul area and most of the clay is of moderately to highly expansive potentials. Recent sediments include sand; mud and gravel are deposited by Tigris River in addition to deposits of clay soil resulting from weathering processes. As a result of repeated flooding of the Tigris River, deposits consist of clay, silt and sand. Most of soil of the western part of this region (which is part of Jezira zone) is undisturbed Miocene and Pliocene limestone, sandstone, and gypsum [14]-[16]. 


\subsubsection{Baghdad Region}

It is located in the central part of Iraq in the upper Mesopotamian zone (Figure 2). The land of this region is used extensively since the dawn of civilization till now because of the high population density. The old inhabitants were depending mainly on the agricultural practices. These practices affected the formations of soil having different sequential layers from place to another over the years. Quaternary flood plain sediments cover the area. These deposits are brought by the Tigris and Euphrates rivers. The main component of soil is silt with some clay and sand [17] [18].

\subsubsection{Basrah Region}

It is located in the southern part of Iraq in the low parts of Mesopotamian plain. The surface of the region is flat and covered by Quaternary fluvial deposits of the Tigris and Euphrates rivers and marsh/lacustrine sediments of southern part of the region. In some area of Basrah region, such as Al-Fao, it is covered with $5 \mathrm{~m}$ thick of highly expansive clay [19] [20].

\section{Calculations}

The design and analysis of a hypothetical building was prepared using STAAD Prov8i software for the average and minimum bearing capacity for the three regions (Mosul, Baghdad and Basrah) of Iraq. The results of compressive strength $\left(f_{c}^{\prime}\right)$ of normal concrete and air-entrained concrete were 37.6 and $52.5 \mathrm{~N} / \mathrm{mm}^{2}$ respectively. While, the density of the normal concrete and air-entrained concrete the concrete were 21.58 and $21.25 \mathrm{~kg} / \mathrm{m}^{3}$ respectively using crush bricks as aggregates in the mixture [8].

The relationship between elastic modulus of concrete and compressive strength was defined as in the ACI code (ACI-318) as follows [21]:

$$
E_{c}=4734 \sqrt{f_{c}^{\prime}} .
$$

The results of calculating modules of elasticity of concrete $\left(E_{c}\right)$ are given in Table 1 :

Table 1. Results of modules of elasticity of concrete.

\begin{tabular}{|c|c|c|c|}
\hline $\begin{array}{l}\text { Compressive strength of } \\
\text { normal concrete }\left(\mathrm{N} / \mathrm{mm}^{2}\right) \\
\qquad f_{c}^{\prime}\end{array}$ & $\begin{array}{c}\text { Modules of elasticity } \\
\text { of concrete } \\
E_{c}\end{array}$ & $\begin{array}{l}\text { Compressive strength of } \\
\text { air-entrained concrete }\left(\mathrm{N} / \mathrm{mm}^{2}\right) \\
\qquad f_{c}^{\prime}\end{array}$ & $\begin{array}{c}\text { Modules of elasticity } \\
\text { of concrete } \\
\mathrm{E}_{\mathrm{c}}\end{array}$ \\
\hline 37.6 & 2.902 & 2.125 & 2.9179 \\
\hline
\end{tabular}

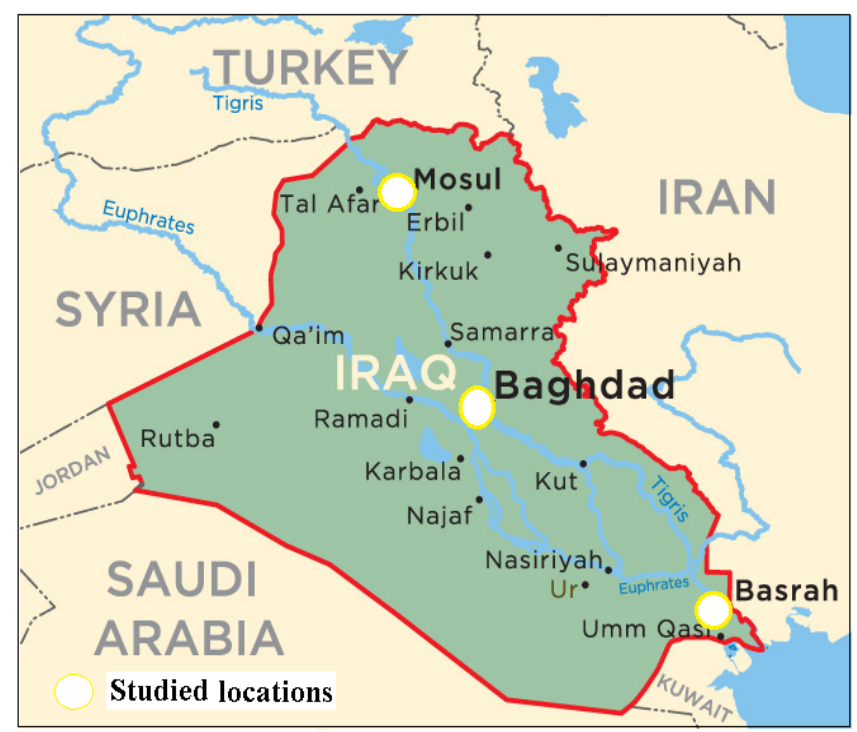

Figure 2. Study areas locations on Iraq Map. 
The values of the density of concrete and the values of modules of elasticity for both normal strength and air-entrained concrete (from Table 1) were used in STAAD Pro software. These values applied for the three locations (Mosul, Baghdad and Basrah) of Iraq.

\section{Results and Discussion}

The input model data used in the software were depending on the field and laboratory tests done for twenty three sites in the three locations (Mosul, Baghdad and Basrah).

The concrete properties used in software were those obtained by Khalaf (2006). The values of density and modules of elasticity $\left(E_{c}\right)$ for concrete were used for both normal strength and air-entrained concrete in STAAD Pro software. The analysis was carried out for the three regions (Mosul, Baghdad and Basrah) in Iraq and for the average and minimum values of bearing capacity for each region. Figures 3-5 and Figure 6 show the results of base pressure under foundation for Mosul locations as an example.

The results for the values of base pressure under foundation for the three locations and for the two types (normal strength and air-entrained) of concrete were lower than that when using standard concrete. This is due to the low density of the concrete mixed with the crush brick for the two types. The density of the standard concrete (according to ACI code) is $2400 \mathrm{~kg} / \mathrm{m}^{3}$. Whilst, the density of concrete used in the software according to ACI code was $235,616 \mathrm{~kg} / \mathrm{m}^{3}$ when using crush brick the concrete density is $8 \%-13 \%$ less [8]. The base pressure under the foundation in Figures 3-6 are tabulated in Table 2 for the three locations of Iraq.

Comparing these results of the base pressure for the three locations with previous work done by [13] using standard concrete, the base pressure values obtained in the previous work [13] were higher than the values obtained in this work as shown in Table 3. This is due to the fact that the density of the concrete mixed with crush brick is lower than that in the case of standard concrete. This type of concrete can be useful to be used in choosing the foundation type when there is problem in the soil of the site. It will also reduce the costs of the constructions due to availability of the brick as a local material.

Table 2. Base pressure values for new mixing concrete for the three locations.

\begin{tabular}{clcc}
\hline & Locations & $\begin{array}{c}\text { Base pressure value for } \\
\text { normal strength }(\mathrm{kPa})\end{array}$ & $\begin{array}{c}\text { Base pressure value for } \\
\text { air-entrained }(\mathrm{kPa})\end{array}$ \\
\hline \multirow{3}{*}{ Mosul } & Average bearing capacity & 80 & 78 \\
& Minimum bearing capacity & 77 & 76 \\
Baghdad & Average bearing capacity & 82 & 75 \\
& Minimum bearing capacity & 79 & 77 \\
\hline
\end{tabular}

Table 3. Comparison between using standard concrete and new concrete.

\begin{tabular}{|c|c|c|c|c|}
\hline & Locations & $\begin{array}{l}\text { Maximum base pressure } \\
\text { value for standard } \\
\text { concrete }(\mathrm{kPa})\end{array}$ & $\begin{array}{l}\text { Maximum base pressure } \\
\text { value for normal } \\
\text { strength }(\mathrm{kPa})\end{array}$ & $\begin{array}{l}\text { Maximum base } \\
\text { pressure value for } \\
\text { air-entrained }(\mathrm{kPa})\end{array}$ \\
\hline \multirow{2}{*}{ Mosul } & Average bearing capacity & 102 & 94 & 91 \\
\hline & Minimum bearing capacity & 89 & 84 & 82 \\
\hline \multirow{2}{*}{ Baghdad } & Average bearing capacity & 96 & 89 & 86 \\
\hline & Minimum bearing capacity & 88 & 82 & 81 \\
\hline \multirow{2}{*}{ Basrah } & Average bearing capacity & 90 & 84 & 82 \\
\hline & Minimum bearing capacity & 80 & 77 & 76 \\
\hline
\end{tabular}




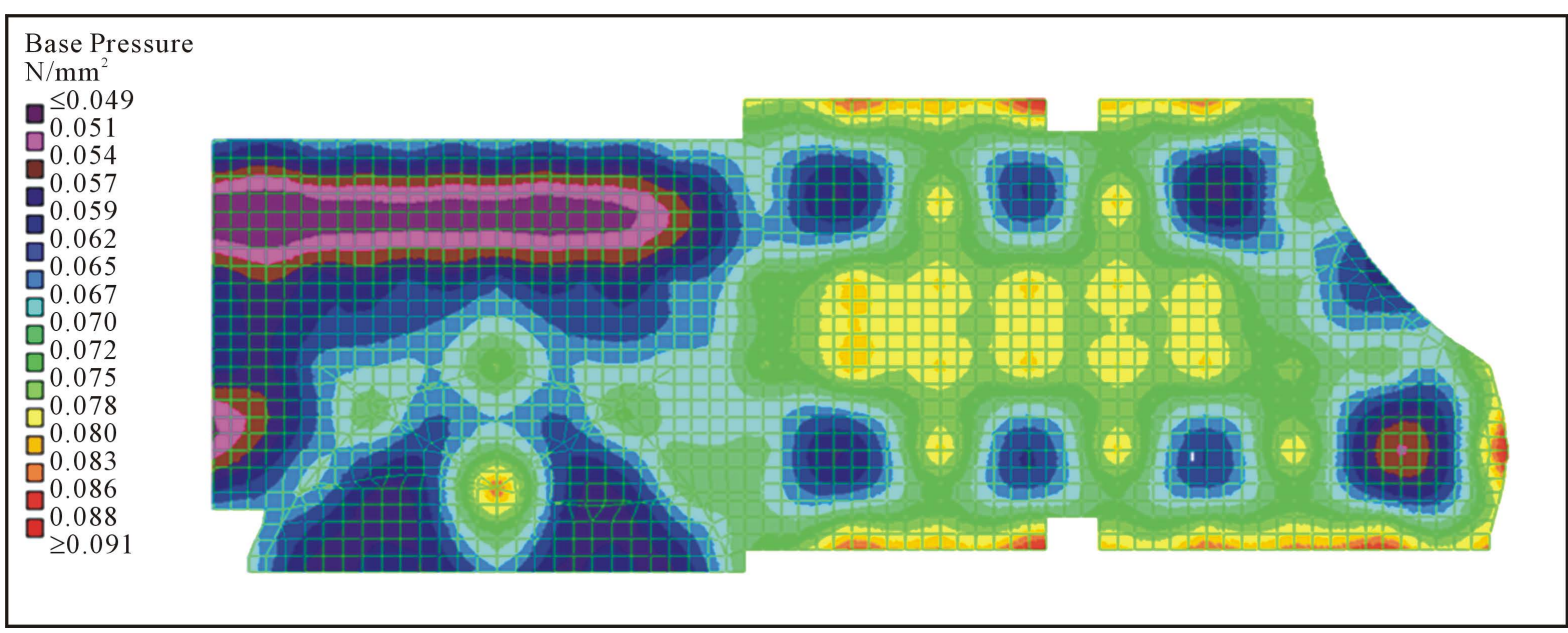

Figure 3. Base pressure distribution using concrete with crush brick as aggregates for air-entrained for Mosul (average value).

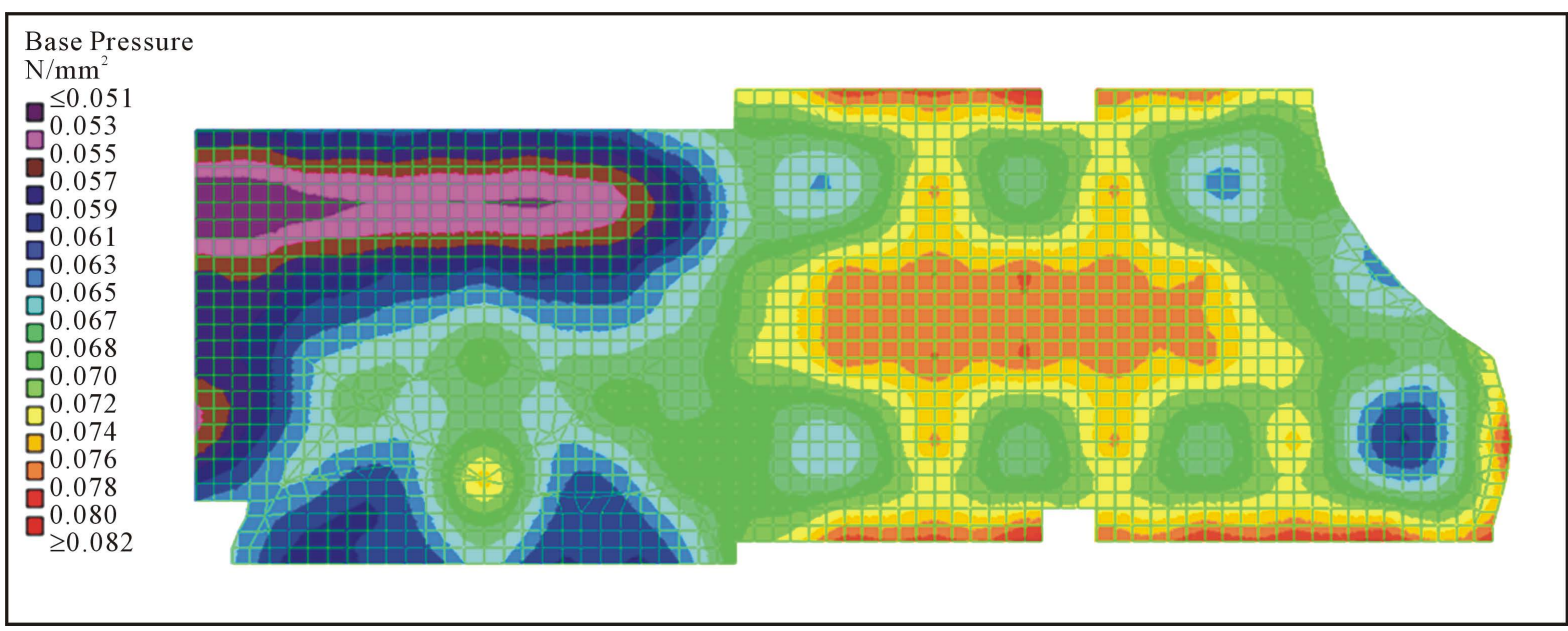

Figure 4. Base pressure distribution using concrete with crush brick as aggregates for air-entrained for Mosul (minimum value).

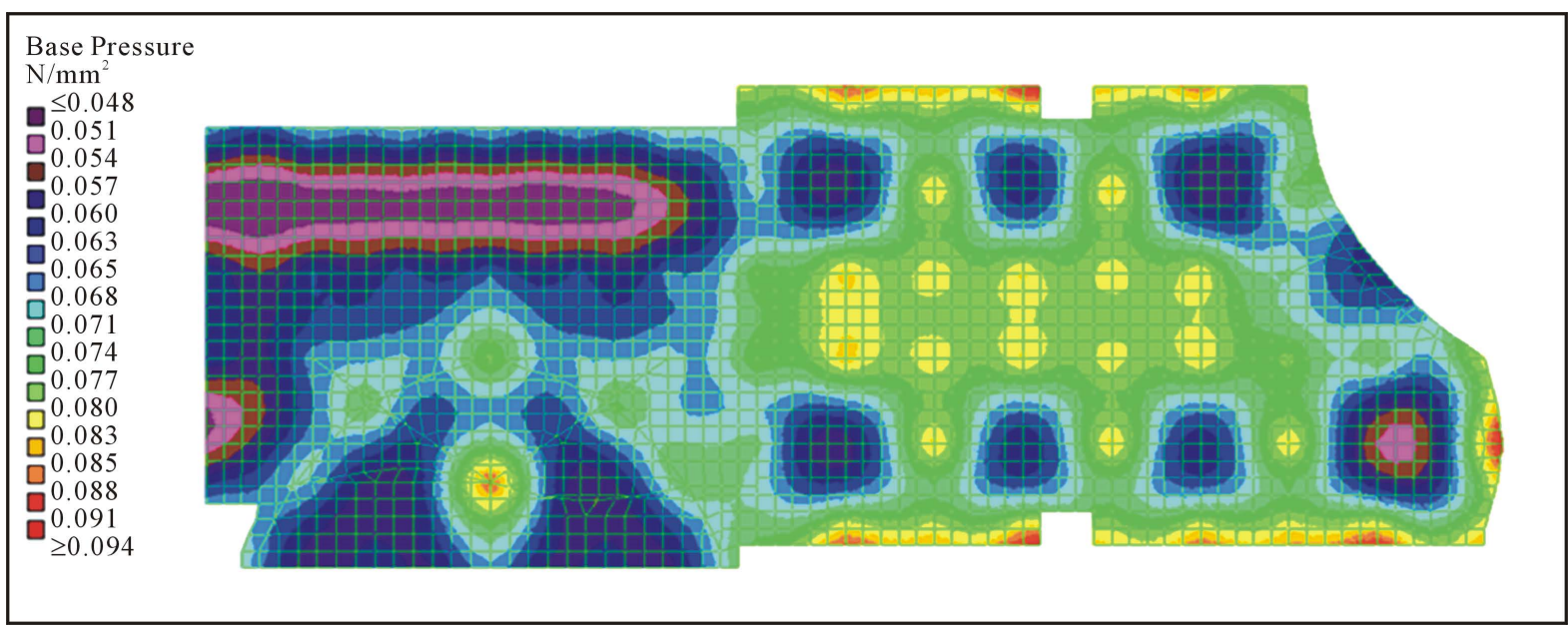

Figure 5. Base pressure distribution using concrete with crush brick as aggregates for normal strength for Mosul (average value). 


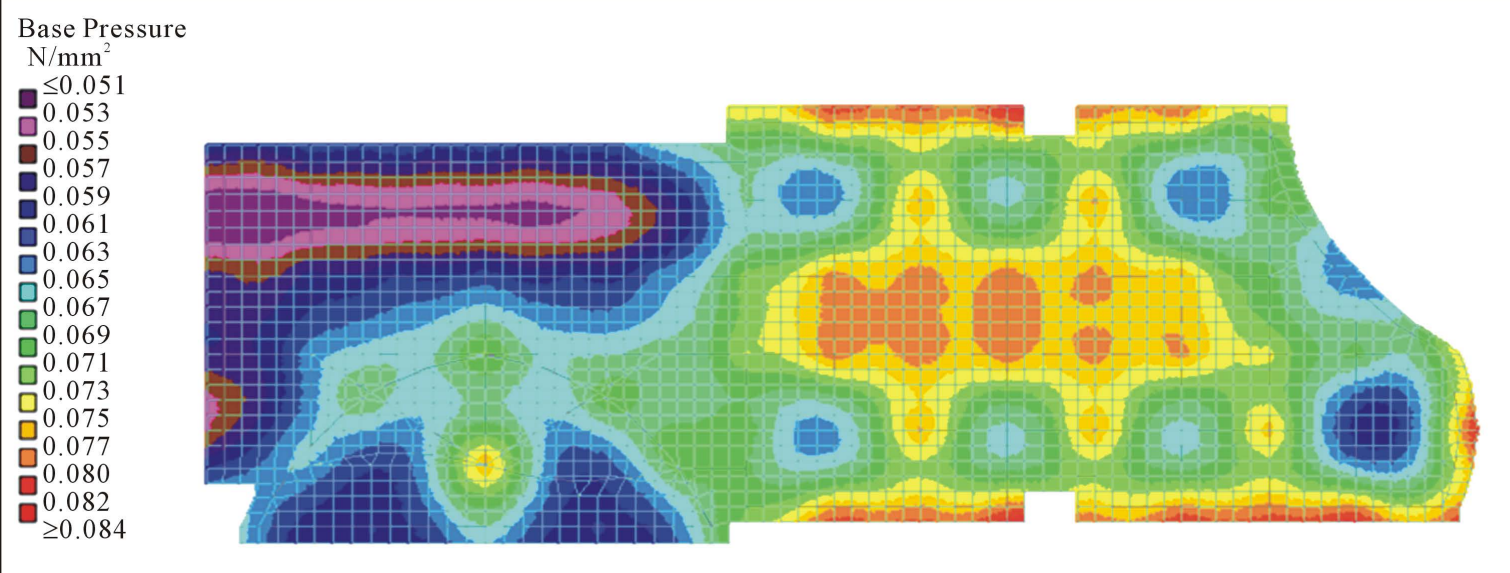

Figure 6. Base pressure distribution using concrete with crush brick as aggregates for normal strength for Mosul (minimum value).

\section{Conclusions}

Brick is a local sustainable material because clay has been proved as sustainable building materials. The use of crush brick as aggregate in concrete mixture gives lower concrete density relative to the standard concrete. This result is reflected on the stresses (dead loads) of the building on the soil beneath the foundation. Moreover, the size and type of foundation can be reduced and changed, which reduces the costs of buildings.

STAAD Prov8i software used to design and analysis a hypothetical building in the three regions of Iraq (Mosul, Baghdad and Basrah). The results showed that the base pressure under the foundation was less compared with the previous work for all locations using standard concrete. Use of crush brick is economical due to it is availability as local material, durability and low prices.

\section{References}

[1] Kamel, M.S. (2010) Cities Constructions towards a Better Future. First Arabic Construction Conference, The League of Arab States, 23-26 December 2010, Cairo.

[2] Abdul Razzaq, N.K. (2012) Planning and Design Characteristics of the Buildings and Settlements of Mud in Iraq. Journal of Planned and Development, 25, 93-111.

[3] Abib, Z.E., Gaher-Abib, H. and Kharchi, F. (2013) Effect of Clay Fines on the Behavior of Self-Compacting Concrete. Engineering, 5, 213-218. http://www.scirp.org/journal/eng

[4] Dey, G. and Pal, J. (2013) Use of Brick Aggregate in Standard Concrete and Its Performance in Elevated Temperature. IACSIT International Journal of Engineering and Technology, 5, 523-526. http://dx.doi.org/10.7763/IJET.2013.V5.610

[5] Bhanbhro, R., Memon, I., Ansari, A., Shah, A. and Memon, B.A. (2014) Properties Evaluation of Concrete Using Local Used Bricks as Coarse Aggregate. Engineering, 6, 211-216. http://www.scirp.org/journal/eng

[6] Kallak, F.S. (2009) Use of Crushed Bricks as Coarse Aggregate in Concrete. Tikrit Journal of Engineering Sciences, 16, 64-69.

[7] Rekha, K. and Potharaju, M. (2015) Residual Compressive Strength of Recycled Brick Aggregate Concrete at High Temperatures. International Journal of Emerging Technology and Advanced Engineering, 5, 159-164.

[8] Khalaf, F.M. (2006) Using Crushed Clay Brick as Coarse Aggregate in Concrete. Journal of Materials in Civil Engineering, 18, 518-526.

[9] Arya, U., Hussain, A. and Khan, W. (2014) Wind Analysis of Building Frames on Sloping Ground. International Journal of Scientific and Research Publications, 4, 1-7.

[10] Subramani, T. and Ponnuvel, D. (2012) Seismic and Stability Analysis of Gravity Dams Using Staad PRO. International Journal of Engineering Research and Development, 1, 44-54.

[11] Meera, C.M. (213) Pre-Engineered Building Design of an Industrial Warehouse. International Journal of Engineering Sciences \& Emerging Technologies, 5, 75-82.

[12] Thakur, A. and Singh, A. (2014) Comparative Analysis of a Multi Storied Residential Building with a without Shear 
Wall Using STADD Pro. International Journal of Recent Research Aspects, 1, 54-57.

[13] Al-Taie, E., Al-Ansari, N. and Knutsson, S. (2014) Effect of Bearing Capacity on Designing Foundations in Iraq Using STAAD Pro-v8i. Engineering, 6, 292-303. http://dx.doi.org/10.4236/eng.2014.66033

[14] Al-Juboury, A.I., Ghazal, M.M. and Mccann, T. (2009) Detrital Chromian Spinels from Miocene and Holocene Sediments of Northern Iraq: Provenance Implications. Journal of Geosciences, 54, 289-300.

[15] Kattab, S.A., Abd, R.S. and Abdulla, B.M.A. (2013) Spatial Analysis of Some Geotechnical Properties for the Left Side of Mosul City Using GIS System. Tikrit Journal of Science and Engineering, 20, 12-17.

[16] Al-Dewachi, B.M. (2005) Origin of Caves in Quaternary Fluvial Deposits at the Left Side of Mosul City-Iraq. Iraqi Journal of Earth Science, 5, 58-67.

[17] Ail, S.M. (2012) Hydrogeological Environmental Assessment of Baghdad Area. Ph.D. Thesis, College of Science, University of Baghdad, Iraq.

[18] Al-Taie, E., Al-Ansari, N. and Knutsson, S. (2014) Bearing Capacity Affecting the Design of Shallow Foundation in Various Regions of Iraq Using SAP200 \& SAFE Softwares. Journal of Earth Sciences and Geotechnical Engineering, 4, 35-52.

[19] Mahmoud, R.A. and Daham, H.A. (2012) expansive Characteristics for Surface Soils in Selected Areas of Alfaw City of Basra Province/South Iraq. Basra Science Journal, 2B, 1-8.

[20] Almutury, W.Gh. and Al-Asadi, M.M. (2008) Tectonostratigraphic History of Mesopotamian Passive Margin during Mesozoic and Cenozoic, South Iraq. Journal of Kirkuk University, 3, 31-50.

[21] Anbuvelan, K. and Subramanian, K. (2014) An Empirical Relationship between Modulus of Elasticity, Modulus of Rupture and Compressive Strength of M60 Concrete Containing Metakaolin. Research Journal of Applied Sciences, Engineering and Technology, 8, 1294-1298. 